\title{
Aplikasi E-Agri Kabupaten Minahasa Selatan
}

\author{
Miranthy F. Takalelumang, Yaulie Deo. Y. Rindengan, Alwin Sambul \\ Teknik Informatika Universitas Sam Ratulangi Manado, Indonesia. \\ miranthy@hotmail.com, rindengan@unsrat.ac.id, asambul@gmail.com
}

\begin{abstract}
Abstrak -Perkembangan teknologi internet mendorong berkembangnya juga aplikasi web yang dimanfaatkan dalam bidang pertanian atau disebut E-Agri. E-Agri atau Electronic Agriculture merupakan kegiatan pertanian yang memanfaatkan keunggulan dari teknologi. Perancangan ini dibuat karena sektor pertanian di Minahasa Selatan pemanfaatan dalam pengolahan dan penyampaian datanya belum efisien. Metode pengembangan yang digunakan dalam perancangan dan pembuatan perangkat lunak ini adalah Rapid Application Development (RAD). Dalam pembuatan perangkat lunak ini penulis menggunakan perangkat lunak PHP dan Adobe Dreamweaver CS6 dan untuk database menggunakan MySQL. Hasil penelitian ini menunjukkan bahwa Aplikasi E-Agri mampu melakukan pengolahan data pertanian seperti menginput data, menyimpan data, mengedit data dan menghapus data sehingga lebih memudahkan dalam pengolahan data yang ada.
\end{abstract}

Kata kunci : Aplikasi, E-Agri, MySQL, Minsel, Rapid Application Development, Web

\section{I.PENDAHULUAN}

Perkembangan teknologi internet yang dari waktu ke waktu semakin pesat, mendorong sebagian lapisan masyarakat untuk memanfaatkannya. Salah satu manfaat dari internet saat ini yaitu dalam bidang pengolahan informasi. Pengolahan informasi yang berbasis komputerisasi adalah menggunakan aplikasi web. Aplikasi web yang saat ini berkembang akibat pekembangan teknologi internet karena dengan menggunakan teknologi internet dapat membantu dalam kemudahan serta kecepatan pengiriman, penyampaian dan penerimaan informasi. Mulai dari perusahaanperusahaan, instansi pemerintah, sekolah-sekolah, perguruan tinggi dan lembaga atau organisasi lainnya telah banyak memanfaatkan aplikasi web dalam kegiatan penjualan, promosi, belajar dan kegiatan lainnya dimana dibutuhkan pengiriman, penyebaran dan penerimaan informasi sehingga memberikan kemudahan bagi pengguna (user) yang membutuhkan.

Sektor pertanian sampai saat ini masih memegang peranan penting didalam menunjang perekonomian nasional. Hal ini disebabkan oleh sebagian besar masyarakat Indonesia bekerja dan hidup dari sektor pertanian, sehingga perekonomian Indonesia masih sangat tergantung pada pertanian. Sektor pertanian sebagai penyedia pangan dan bahan baku industri, pendorong pencipta lapangan kerja perdesaan dan devisa negara. Sektor pertanian juga mempunyai peranan penting dalam mengentaskan kemiskinan. Pembangunan pertanian berkaitan baik secara langung maupun tidak langsung dengan upaya peningkatan kesejahteraan petani dan upaya menanggulangi kemiskinan khususnya di daerah perdesaan (Harianto, 2014).

Provinsi Sulawesi Utara merupakan salah satu Provinsi dengan tingkat pendapatan ekonomi dari sektor pertanian yang cukup tinggi. Salah satu daerah yang mempunyai potensi di bidang pertanian adalah Kabupaten Minahasa Selatan. Potensi pertanian di Kabupaten Minahasa Selatan dengan ketersediaan lahan yang subur sangat cocok untuk pengembangan berbagai jenis komoditas pertanian.
Saat ini proses pertanian di Kabupaten Minahasa Selatan belum termonitor dan terkontrol dengan baik sehingga sering kali terjadi kelangkaan ataupun melunjaknya suatu komuditas tertentu yang mengakibatkan kerugian. Sistem konvensional yang dipakai untuk melaporkan kondisi pertanian di daerah ini masih sangat memakan waktu, banyak laporan yang terlambat mengakibatkan penangggulangan yang lambat oleh karena itu penulis akan membuat penelitian dengan judul "Aplikasi E-Agri Kabupaten Minahasa Selatan" agar sistem pertanian yang ada di daerah ini bisa termonitor dan terkontrol dengan baik.

\section{LANDASAN TEORI}

\section{A. E-Agri}

Pengertian e-Agri sendiri diambil dari definisi e (electronic) dalam konsep Information and Communication Technology (ICT), yaitu kegiatan pertanian dan/atau agribisnis yang memanfaatkan keunggulan ICT seperti komputer, internet, piranti lunak (software) dan piranti keras (Hardware), radio, televisi dan perangkat IT lainnya, serta orang yang mengoprasikan ICT tersebut. Aplikasi $e$ Agriculture atau e-Agribusiness dapat dilakukan di semua aktivitas pertanian dari mulai kegiatan di hulu (proses produksi) sampai pada hilir(pemasaran hasil). FAO telah memanfaatkan ICT di kegiatan network, publikasi, database dan pembuatan Web [1].

\section{B. Pemanfaatan ICT dalam Pertanian}

Kini ICT juga dicoba untuk mendorong agar pertanian Indonesia mampu bersaing. Hal ini dapat dimengerti karena peran ICT sering menonjol, apakah itu di kegiatan teknologi produksi maupun di kegiatan teknologi informasi. Dengan demikian, lambat atau cepat, maka pelaku agribisnis di Indonesia harus bisa menguasai teknologi tersebut.

Komponen ICT ini lazimnya dapat dikelompokkan menjadi empat, yaitu :

1. Technoware (fasilitas fisik, misalnya mesin)

2. Humanware(kemampuan/ketrampilan tenaga kerja)

3. Infoware (informasi/data)

4. Orgaware (organisasi)

Misalnya untuk tingkat pembangunan suatu perusahaan hasil olahan dari produk pertanian, bantuan ICT akan sangat menentukan proses kegiatan perusahaan tersebut. Keempat kompenen diatas, tentu saling kait mengkait satu sama lain, karena komponen yang satu akan saling mempengaruhi komponen yang lain.

\section{Aplikasi}

Aplikasi atau program aplikasi adalah program yang ditujukan untuk menyelesaikan suatu permasalahan dalam aplikasi tertentu (Hartono, 2002:398). Aplikasi adalah penggunaan atau penerapan suatu konsep yang menjadi pokok pembahasan. Aplikasi dapat diartikan juga sebagai program komputer yang dibuat untuk menolong manusia dalam melaksanakan tugas tertentu. Aplikasi software yang dirancang untuk penggunaan praktisi khusus, klasifikasi luas ini dapat dibagi menjadi 2 (dua) yaitu: (www. storage.jak-stik.ac.id)

1. Aplikasi software spesialis, program dengan dokumentasi tergabung yang dirancang untuk menjalankan tugas tertentu.

2. Aplikasi paket, suatu program dengan dokumentasi tergabung yang dirancang untuk jenis masalah tertentu. 
Menurut Whitten Perancangan Sistem adalah "Proses dimana keperluan pengguna dirubah ke dalam bentuk paket perangkat lunak dan atau kedalam spesifikasi pada komputer yang berdasarkan pada sistem informasi." Kristanto(1994:60 ).

\section{Pengantar Web}

Untuk mendapatkan sebuah informasi, sekumpulan protokol harus digunakan, yaitu sekumpulan aturan yang menetapkan bagaimana suatu informasi dapat dikirim dan diterima. Salah satu unsur yang paling umum digunakan dari internet selain e-mail adalah World Wide Web. Dewasa ini WWW atau sering disebut juga "Web" saja merupakan aplikasi internet yang paling populer. Karena web begitu populer, banyak orang kemudian salah mengidentikkannya dengan internet (Simarmata, 2006). Secara teknis, Web adalah sebuah sistem dengan informasi yang disajikan dalam bentuk teks, gambar, suara dan lain-lain yang tersimpan dalam sebuah server $W e b$ Internet yang disajikan dalam bentuk hiperteks. Informasi web dalam bentuk teks umumnya ditulis dalam format HTML (Hypertext Markup Language). Informasi lainnya disajikan dalam bentuk grafis (dalam format GIF, JPG, PNG), suara dalam format (AU, WAV) dan objek multimedia lainnya (seperti MIDI, Shockwave, Quicktime Movie, 3D World).

\section{E. Aplikasi Berbasis Web}

Aplikasi berbasis web (web based apllication) adalah aplikasi yang dapat dijalankan langsung melalui web browser bisa menggunakan internet ataupun intranet dan tidak tergantung pada sistem operasi yang digunakan (Rizky, 2010).

Unsur-unsur dalam web adalah sebagai berikut:

1. Internet

Internet merupakan kepanjangan dari internetconnection Networking. Internet merupakan rangkaian jaringan terbesar di dunia dimana semua jaringan yang berada pada semua organisasi dihubungkan dengan suatu jaringan terbersar melalui telepon, satelit dan sistemsistem komunikasi yang lain sehingga saling berkomunikasi (Mulyanto, 2009:113).

Untuk dapat bertukar informasi, digunakan protocol standar yaitu Transmision Control Protocol dan Internet Protocol yang lebih dikenal sebagai TCP/IP. Sedangkan internet merupakan jaringan komputer didalam suatu organisasi yang menggunakan teknologi internet sehingga memungkinkan saling berbagi informasi, komunikasi, kerja sama dan dukungan bagi proses bisnis.

2. Nama Domain/URL

Nama domain atau URL adalah alamat unik didunia internet yang digunakan untuk mengidentifikasi sebuah website. Nama domain memudahkan user dalam mengingat alamat IP. Layanan yang bertugas menerjemahkan alamat IP kesebuah nama domain adalah DNS (Domain Name Service)

3. Web Browser

Web browser merupakan aplikasi dipihak client yang berfungsi menerjemahkan dan menampilkan informasi dari server secara grafis kepada client.

4. Web Server

Sebuah komputer (server) dan software yang menyimpan dan mendistribusikan data komputer lainnya melalui jaringan internet.

5. Web Hosting

Web hosting yaitu sebagai ruangan yang terdapat dalam harddisk tempat menyimpan berbagai data, file-file, gambar dan lain-lain yang akan ditampilkan di website.

Aplikasi berbasis $W e b$ memiliki beberapa kelebihan sebagai berikut :

a. Platform independent yaitu aplikasi dapat dijalankan di berbagai sistem operasi seperti windows, linux dan Mac OS.

b. Untuk menjalankan aplikasi dibanyak komputer tidak perlu install aplikasi disetiap komputer, cukup copy script programnya ke server atau salah satu komputer.
Untuk komputer lain yang ingin menjalankan program cukup membuka alamat host server dimana program disimpan melalui browser.

c. Aplikasi dapat dijalankan dari jarak jauh dengan menggunakan koneksi internet.

\section{F. Sistem Informasi}

Menurut Turban, McLean dan Wetherbe (1999), sistem informasi adalah sebuah sistem yang mempunyai fungsi mengumpulkan, memproses, menyimpan, menganalisis dan menyebarkan informasi untuk tujuan yang spesifik.

Menurut Mc Leod (1992), sistem informasi adalah suatu sistem yang memiliki kemampuan untuk mengumpulkan informasi dari semua sumber dan menggunakan berbagai media untuk menampilkan informasi.

Menurut Bodnar dan Hopwood (1993), sistem informasi adalah kumpulan perangkat keras dan lunak yang dirancang untuk mentransformasikan data ke dalam bentuk informasi yang berguna. Menurut Alter (1992), sistem informasi adalah kombinasi antara prosedur kerja, informasi, orang dan teknologi informasi yang diorganisasikan untuk mencapai tujuan dalam sebuah perusahaan.

Menurut Robert A. Leitch sistem informasi adalah suatu sistem didalam suatu organisasi yang mempertemukan kebutuhan pengolahan transaksi harian, mendukung operasi, bersifat manajerial dan kegiatan strategi dari suatu organisasi dan menyediakan pihak luar tertentu dengan laporan-laporan yang diperlukan.

\section{G. Browser}

Browser merupakan software yang di install dimesin client yang berfungsi untuk menterjemahkan tag-tag HTML menjadi halaman web. browser yang sering digunakan biasanya internet explorer, netscape navigator dan masih banyak yang lainnya (Nur Hasyim, 2003).

\section{H. World Wide Web}

WWW atau World Wide Web maupun web saja adalah sebuah sistem yang saling terkait dalam sebuah dokumen berformat hypertext yang berisi beragam informasi, baik tulisan, gambar, suara, video dan informasi multimedia lainnya dan dapat diakses melalui sebuah perangkat yang disebut web browser.

Untuk menterjemahkan dokumen hypertext kedalam bentuk dokumen yang dapat dipahami oleh manusia, maka web browser melalui web client akan membaca halaman web yang tersimpan disebuah web server melalui protokol yang sering disebut HTTTP atau Hypertext Transfer Protocol.

Perangkat lunak web browser saat ini tersedia dalam berbagai produk dengan kelebihan dan kekurangannya masing-masing. Beberapa web browser yang paling terkenal saait ini adalah mozilla firefox, internet explorer, opera, google chrome, safari dan lain sebagainya.

Dokumen hypertext yang tersimpan didalam sebuah web server memiliki banyak link atau sambungan antara satu dokumen hypertext dengan dokumen hypertext lainnya. Dengan adanya link antar dokumen hypertext, maka hal tersebut dapat memudahkan pengakses untuk meengunjungi atau mendapatkan dokumendokumen terkait yang diinginkannya.

\section{Model RAD (Rapid Application Development)}

RAD merupakan model proses perangkat lunak yang menekankan pada daur pengembangan hidup yang singkat. RAD merupakan versi adaptasi cepat dari model waterfall, dengan menggunakan pendekatan konstruksi komponen (Pressman, 2005).

RAD adalah suatu pendekatan berorientasi objek terhadap pengembangan sistem yang mencakup suatu metode pengembangan serta perangkat-perangkat lunak. RAD bertujuan mempersingkat waktu yang biasanya diperlukan dalam siklus hidup pengembangan sistem tradisional antara perancangan dan penerapan suatu sistem informasi. Pada akhirnya, RAD sama-sama berusaha memenuhi syarat-syarat bisnis yang berubah secara cepat (Kendall, 2010). 
Terdapat tiga fase dalam RAD yang melibatkan penganalisis dan pengguna dalam tahap penilaian, perancangan, dan penerapan. Adapun ketiga fase tersebut adalah requirements planning (perencanaan persyaratan), RAD design workshop (workshop desain RAD), dan implementation (implementasi). Berikut ini adalah tahap-tahap pengembangan aplikasi dari tiap-tiap fase pengembangan aplikasi (Kendall, 2010):

1. Requirements Planning (Analisis Persyaratan)

Dalam fase ini, pengguna dan penganalisis bertemu untuk mengidentifikasikan tujuan-tujuan aplikasi atau sistem serta untuk megidentifikasikan syarat-syarat informasi yang ditimbulkan dari tujuan-tujuan tersebut. Orientasi dalam fase ini adalah menyelesaikan masalahmasalah perusahaan. Meskipun teknologi informasi dan sistem bisa mengarahkan sebagian dari sistem yang diajukan, fokusnya akan selalu tetap pada upaya pencapaian tujuan-tujuan perusahaan.

2. RAD Design Workshop (Pemodelan)

Mengidentifikasi solusi alternatif dan memilih solusi yang terbaik. Kemudian membuat desain proses bisnis dan desain pemrograman untuk data-data yang telah didapatkan dan dimodelkan dalam arsitektur sistem informasi. Tools yang digunakan dalam pemodelan sistem biasanya menggunakan Unified Modeling Language (UML).

3. Implementation (Konstruksi)

Setelah Design Workshop dilakukan, selanjutnya sistem di-implementasikan (coding) ke dalam bentuk yang dimengerti oleh mesin yang diwujudkan dalam bentuk program atau unit program. Tahap implementasi sistem merupakan tahap meletakkan sistem supaya siap untuk dioperasikan.

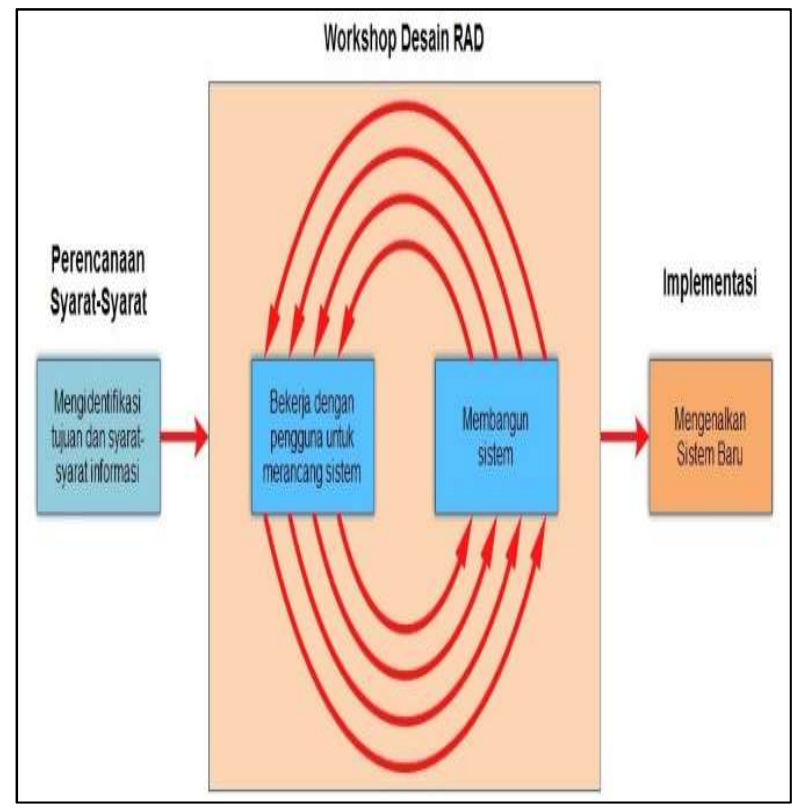

Gambar 1. Siklus RAD (Kendall, 2010)

\section{J. Basis Data}

Basis data merupakan kumpulan dari data yang saling berhubungan satu dengan yang lainnya, tersimpan di perangkat keras komputer dan digunakan perangkat lunak untuk memanipulasinya (Hartono, 2002:711). Istilah basis data pada umumnya juga menyiratkan serangkaian sifat yang terkait; berbagi data, integrasi data, kemanan data, abstraksi data dan independensi data (Simarmata, 2007:6).

\section{K. Sistem Manajemen Basis Data (DBMS)}

Sistem manajemen basis data (DBMS) adalah suatu perangkat lunak kompleks yang mengatur permintaan dan penyimpanan data ke dan dari disk. Sistem manajemen basis data (DBMS) adalah perangkat lunak yang disajikan oleh penjual basis data. Produk perangkat lunak seperti Microsoft Access, Oracle, Microsoft SQL Server, Sybase, DB2, INGRES DAN MySQL adalah semua DBMS (Sumarmata, 2007:14).

\section{MYSQL}

Pengertian MySql menurut (Kadir, 2009), "MySql merupakan software yang tergolong database server dan bersifat open source. Open source menyatakan bahwa software ini dilenkapi dengan source code (kode yang dipakai untuk membuat MySql), selain itu tentu saja bentuk executable-nya atau kode yang dapat dijalankan secara langsung dalam sistem operasi dan bisa diperoleh dengan cara mengunduh di internet secara gratis".

MySql merupakan database server dimana pemrosesan data terjadi diserver dan client hanya mengirim data serta meminta data. Oleh karena pemrosessan terjadi di server sehingga pengaksessan data tidak terbatas. Pengaksesan dapat dilakukan dimana saja oleh siapa saja dengan catatan komputer telah terhubung ke server. Lain halnya dengan database desktop dimana segala pemrosesan data seperti penambahan data ataupun penghapusan data harus dilakukan pada komputer yang bersangkutan.

MySq1 termasuk dalam kategori DBMS (Database Management System), yaitu database yang terstruktur dalam pengolahan dan penampilan data. Sejak komputer dapat menangani data yang besar, DBMS memegang peranan yang sangat penting dalam pengolahan data. Hal ini sangat diperlukan karena data tersebut dapat diatur sesuai dengan kebutuhan pemaikainya.

MySql merupakan Relational Database Management System (RDBMS) yaitu hubungan antar tabel yang berisi suatu data-data pada satu database. Hal tersebut lebih baik daripada jika semua data terkumpul menjadi satu dalam satu tabel. Kelebihan hal diatas, yaitu dapat mempercepat pencarian suatu data. Tabel-tabel tersebut di link (dihubungkan) oleh suatu relasi yang memungkinkan untuk mengkombinasikan data dari beberapa tabel ketika seorang user mengirimkan menampilkan informasi dari suatu database. MySql merupakan database yang dikembangkan dari bahasa SQL (Structured Query Language) merupakan bahasa yang terstruktur yang digunakan untuk interaksi antara script program dengan database server dalam hal pengolahan data. Dengan SQL kita dapat membuat tabel yang nantinya diisi dengan data, memanipulasi data, serta membuat suatu perhitungan dengan berdasarkan data yang ditemukan. Oleh karena itu, SQL tidak hanya perhitungan dengan berdasarkan data yang ditemukan selain itu SQL tidak hanya terbatas digunakan untuk mendapatkan suatu tampilan dari database yang statis.

Sebuah model SQL terdiri atas tabel, baris, field dan elemen. Setiap user pada suatu sistem dapat memiliki database yang terpisah dan independen antara satu dengan yang lainnya. Suatu tabel pada suatu database tidak boleh ada dua data atau lebih yang sama persis.

Ada beberapa alasan sehingga MySql banyak digunakan oleh para web developer antara lain alasannya ialah :

1. MySql merupakan database yang memiliki kecepatan yang tinggi dalam melakukan pemrosesan data, dapat diandalkan dan mudah digunakan serta mudah dipelajari. MySql mudah digunakan karena MySql telah banyak digunakan sehingga jika kita mempunyai masalah dengan database tersebut, kita dapat bertanya kepada orang melalui internet maupun orang sekitar kita yang alam menyelesaikan masalah tersebut serta banyaknya dukungan manual maupun refrensi di internet.

2. MySql mendukung banyak bahasa pemrograman seperti C, C++, Perl, Phyton, Java dan PHP. Kita dapat menggunakan bahasa pemrograman tersebut untuk berinteraksi maupun berkomunikasi dengan MySql server, atau dapat juga digunakan sebagai komponen pembentuk antar muka dari suatu database MySql.

3. Koneksi, kecepatan dan keamanan membuat MySql sangat cocok diterapkan pengaksesan data melalui 
internet, dengan menggunakan bahasa pemrograman Perl atau PHP sebagai antarmukanya.

4. MySql dapat melakukan koneksi dengan client menggunakan TCP/IP.

5. MySql dapat menangani database dengan skala yang sangat besar dengan jumlah record mencapai lebih dari 50 juta, dapat menampung 60 ribu tabel dan juga bisa menampung 5 milyar baris data. Selain itu, batas indeks pada tiaptabel data menampung mencapai 32 indeks.

6. Dalam hal relasi antar tabel pada suatu database, MySq1 menerapkan metode yang sangat cepat, yaitu dengan menggunakan metode one-sweep multijoin. MySql sangat efisien dalam mengelola informasi yang kita minta yang berasal dari banyak table sekaligus.

7. Multi user, yaitu dalam satu database server pada MySql dapat diakses leh beberapa user dalam waktu yang sama tanpa mengalami konflik atau crash.

8. Dalam segi keamanan, MySql memiliki keamananyang luar biasa. Akses user bisa diproteksi menggunakan user validation dalam bentuk terenkripsi.

9. MySql merupakan software aplikasi yang bersifat gratis.

\section{Entity Relationship Diagram (ERD)}

Entity Relationship Diagram merupakan suatu model untuk menjalankan hubungan antar data dalam basis data berdasarkan objek-objek dasar data yang mempunyai hubungan antar relasi. ERD untuk memodelkan struktur data dan hubungan antar data, untuk menggambarkannya digunkan beberapa notasi dan simbol.

a. Entity : Entity merupakan objek yang mewakili sesuatu yang nyata dan dapat dibedakan dari suatu yang lain. Simbol dari entity ini biasanya di simbolkan dengan persegi panjang.

b. Atribut : Setiap entitas pasti mempunyai elemen yang disebut atribut yang berfungsi untuk mendeskripsikan karakteristik dari entitas tersebut. Isi dari atribut mempunyai sesuatu yang dapat mengidentifikasikan isi elemen satu dengan yang lain. Gambar atribut diwakili dengan simbol elips.

c. Hubungan / relasi : Hubungan antara sejumlah entitas yang berasal dari himpunan entitas yang berbeda.

\section{N. Page Hypertext Preprocessor (PHP)}

PHP atau Page Hypertext Preprocessor adalah bahasa yang bersifat server side yang memiliki kemampuan untuk dikombinasikan dengan teks, HTML, dan komponen-komponen lain untuk membuat suatu halaman web lebih menarik, dinamis, dan interaktif. Dengan beberapa kemudahan yang dimiliki oleh PHP, diharapkan pengembang halaman web menjadi mudah dan lebih cepat berkerja. Pada awalnya, PHP diciptakan oleh Andi Gutmans untuk menghitung berapa banyak pengunjung yang mengakses homepage yang dibuat olehnya.

Seiring dengan perkembangan internet, dirilis PHP dan selanjutnya PHP2. Dari sekelompok orang salah satunya Rasmus Lerdort dirilis PHP3 yang merupakan penyempurnaan dari versi sebelumnya. Dalam versi ini, PHP3 telah mampu digunakan untuk membangun aplikasi web dengan koneksi database yang cukup banyak. Namun hanya bekerja dengan baik pada website yang tidak begitu kompleks. Versi PHP4 merupakan pengembangan dari versi PHP3 dengan menambahkan fungsi-fungsi seperti zend engine sehingga lebih cepat, kuat, stabil, mudah untuk berinteraksi dengan berbagai aplikasi pendukungnya.

\section{O. Hyper Text Markup Language (HTML)}

HTML (Hypertext Markup Language) merupakan bahasa markup yang dapat dimengerti, diterjemahkan dan ditampilkan oleh browser. HTML menggambarkan format dan isi dari dokumen, yang pada dasarnya terdiri dari teks yang statis dan gambar. HTML ditemukan oleh Berners-Lee bersamaan dengan ditemukannya protokol yang disebut HTTP atau HyperText Transfer Protocol (Darie, 2006, 10).

HTML pada awalnya tidak dirancang untuk membangun aplikasi web yang kompleks dengan konten yang interaktif atau antarmuka yang user-friendly. Untuk melakukan navigasi antar halaman via HTTP, seluruh halaman web perlu reload, serta web yang diminta harus ada pada lokasi yang dicantumkan sebagai suatu dokumen statis. Jadi pengguna HTML dengan HTTP sangat terbatas pada respon berupa kontent yang statis (Darie, 2006, 11).

\section{P. Adobe Dreamweaver CS6}

Menurut Macdoms (2010), "Dremweaver adalah merupakan software aplikasi yang digunakan sebagai HTML editor profesional untuk mendesain web secara visual. Aplikasi ini juga biasa dikenal juga dengan istilah WYSIWYG (What You See It What You Get), yang artinya tidak harus berurusan dengan tag-tag HTML untuk membuat situs."

Untuk memahami elemen ruang kerja dreamweaver CS6, bukanlah sebuah file HTML baru dalam dreamweaver CS6. Setelah dreamweaver CS6 berhasil dijalankan, pilih file baru (create new) tipe HTML didalam kotak dialog New Document yang tampil. Ruang kerja dasar dreamweaver CS6, yaitu :

1. Application Bar, berada dibagian paling atas jendela aplikasi dreamweaver CS6. Baris ini berisi tombol workspace (workspace switcher), CS Live, menu dan aplikasi lainnya.

2. Toolbar Document, berisi tombol-tombol yang digunakan untuk mengubah tampilan jendela dokumen, sebagai contoh tampilan design atau tampilan code. Juga dapat digunakan untuk operasi-operasi umum, misalnya untuk melihat hasil sementara halaman web pada jendela browser.

3. Jendela dokumen, adalah lembar kerja tempat membuat dan mengedit design halaman web.

4. Workspace Switcher, digunakan untuk mengubah tampilan ruang kerja dreamweaver CS6.

5. Panel Groups, adalah kumpulan panel yang saling berkaitan, panel-panel ini dikelompokkan pada juduljudul tertentu berdasarkan fungsinya. Panel ini di gunakan untuk memonitor dan memodifikasi pekerjaan. Secara default, panel group berisi panel Adobe BrowserLab, Adobe Bussiness Catlyst, Insert, CSS Styles, Asset, AP Element dan Files.

6. Tag Selector, diletakkan dibagian bawah jendela dokumen, satu baris dengan status bar. Bagian ini menampilkan hirarki pekerjaan yang sedang terpilih pada jendela dokumen, dapat juga digunakan untuk memilih objek pada jendela design berdasarkan jenis atau kategori objek tersebut. Tag selector juga menampilkan informasi format dari bagian yang sedang aktif pada lembar kerja design.

7. Property Inspector, digunakan untuk melihat dan mengubah berbagai properti objek atau teks pada jendela design. Properti untuk satu objek dengan objek lainnya selalu berbeda-beda. Jendela ini tidak dapat diuraikan pada tampilan jendela code.

8. Toolbar Stamdart, baris toolbar ini berisi tombol-tombol yang mewakili perintah pada menu File dan Edit, diantaranya perintah new, Open, Save, Save All, Cut, Copy, Paste, Undo dan Redo.

9. Toolbar Style Rendering, secara default disembunyikan. Toolbar ini berisi tombol-tombol untuk menampilkan design dalam media berbeda. Selain itu juga digunakan untuk mengaktifkan dan menonaktifkan style CSS.

10. Toolbar Coding, berisi tombol-tombol yang digunakan untuk melakukan operasi kode-kode standar. Toolbar ini hanya tampil pada jendela code.

11. Toolbar Browser Navigation, toolbar ini adalah toolbar yang baru ada didalam dreamweaver CS6 dan letaknya tepat diatas jendela dokumen. Toolbar ini berisi tomboltombol yang digunakan sebagai navigasi didalam browser. 


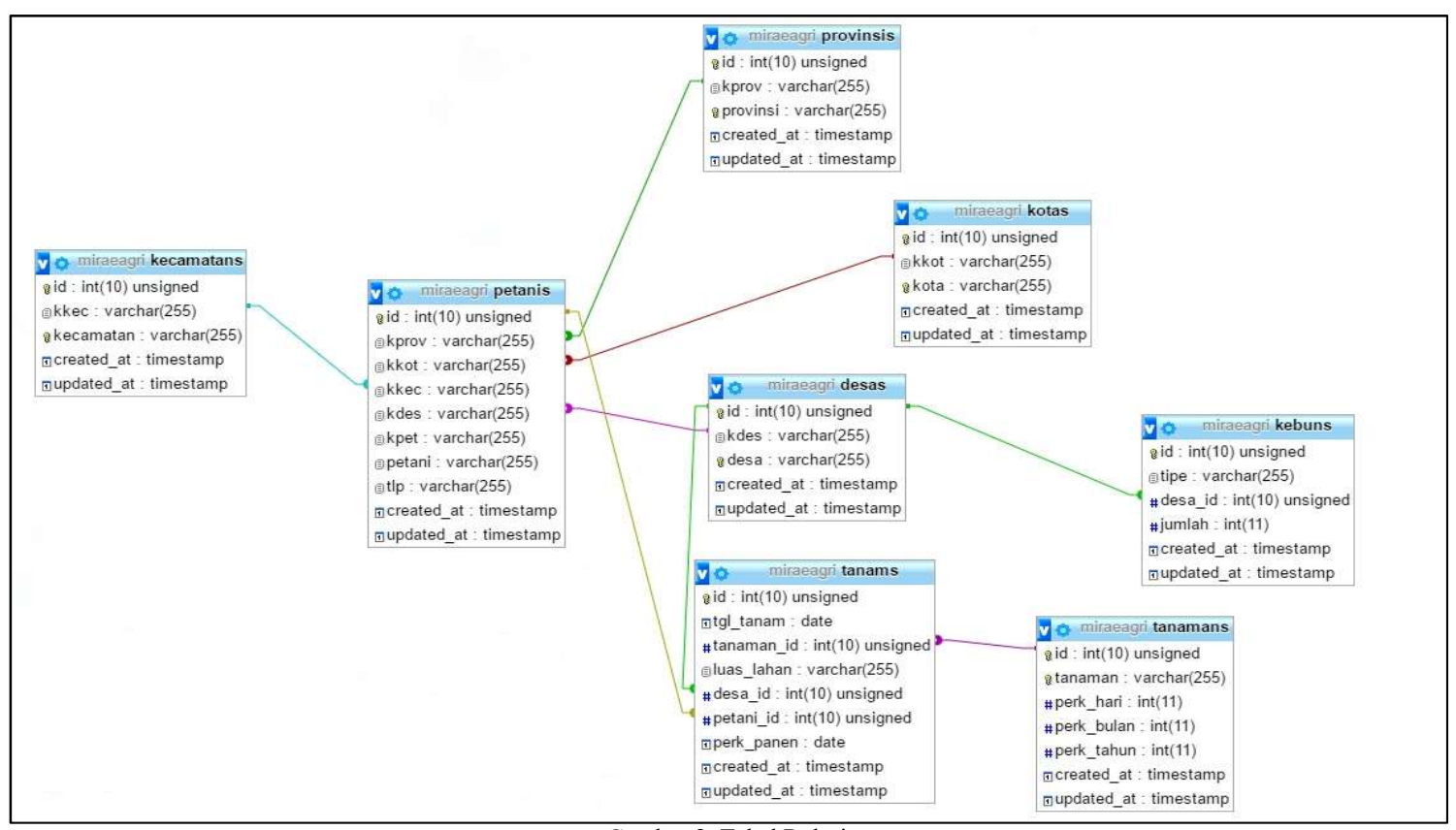

Gambar 2. Tabel Relasi

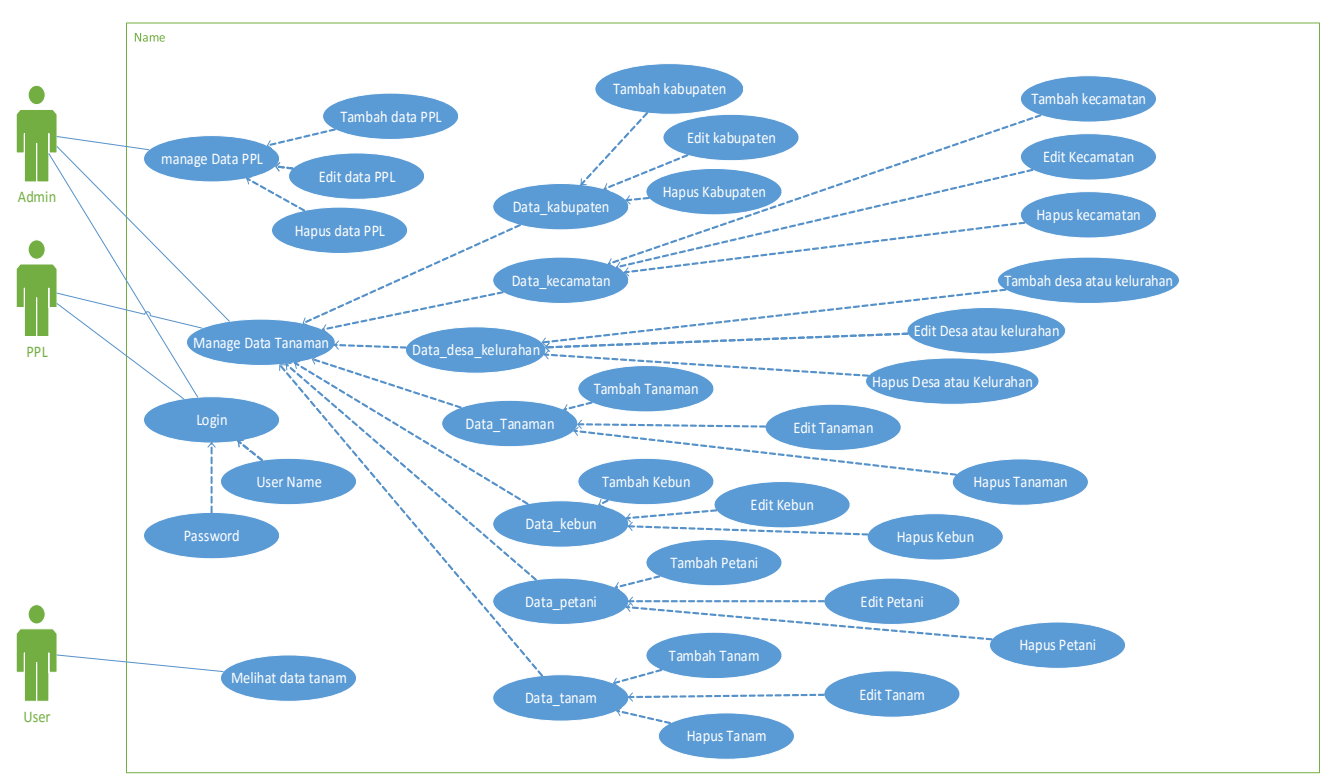

Gambar 3. Use Case Diagram Aplikasi E-Agri

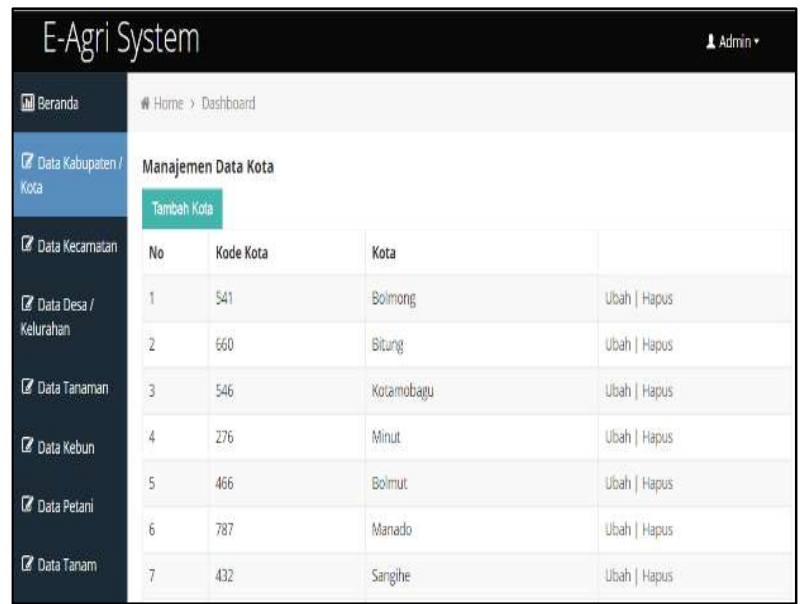

Gambar 4. Tampilan Menu Data Kabupaten/kota pada admin

\section{METODE PENELITIAN}

A. Bentuk-bentuk metode penelitian penulis sebagai berikut:

1. Objek Penelitian

Pelaksanaan penelitian dilakukan di Provinsi Sulawesi Utara yang pengambilan data penelitian dilokasikan di Kabupaten Minahasa Selatan sebagai objek penelitian.

\section{Analisa Data}

Tahapan selanjutnya adalah Analisa data yang dibagi dalam 2 jenis data yang akan menjadi kebutuhan aplikasi E-Agri yang akan dibangun yaitu : 


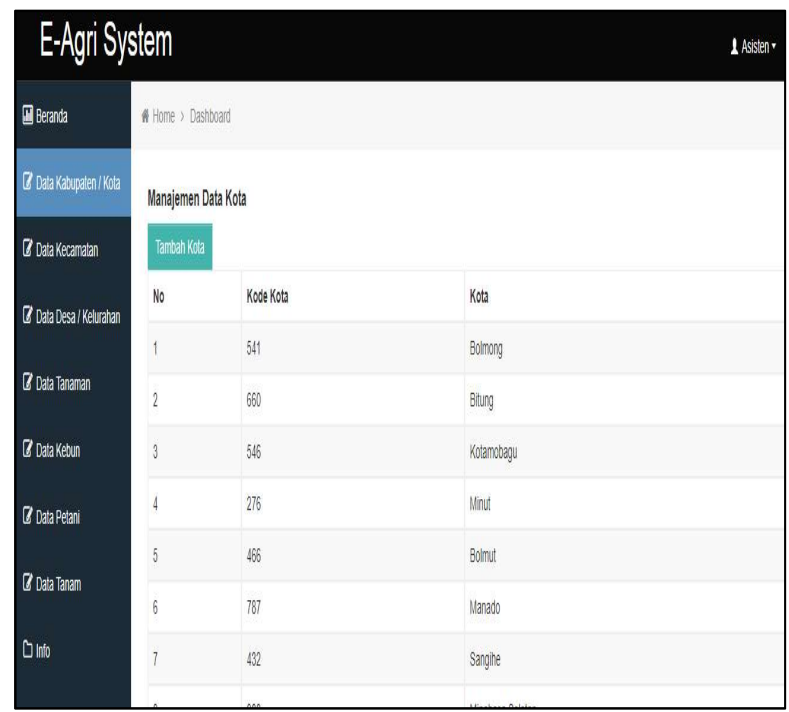

Gambar 5. Tampilan men data kabupaten/kota pada asisten

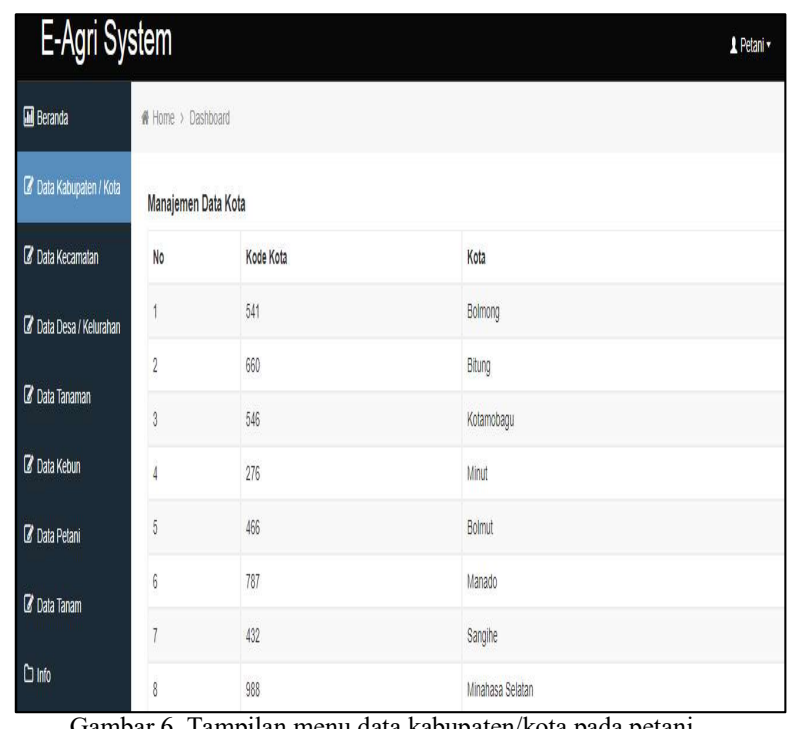

Gambar 6. Tampilan menu data kabupaten/kota pada petani

a. Data Primer

Data primer diperoleh dengan langkah komuikasi dan perencanaan proyek yang bertujuan untuk mengidentifikasi kegiatan, patokan dana apa saja yang harus dihasilkan proyek. Aktifitas yang dilakukan yaitu dengan melakukan wawancara.

b. Data Sekunder

Data sekunder merupakan data pendukung dalam penelitian ini. Data ini didapatkan melalui proses studi pustaka mengenai penelitian-penelitian terkait dan dirangkum menjadi sebuah konstribusi penelitian.

3. Pemodelan Interaksi Obyek dan Behavior

Langkah yang bertujuan untuk mengidentifkasi dan mengelompokkan perancangan objek dan atribut-atribut yang dibutuhkan secara fungsional. Langkah ini dipaparkan dengan tabel relasi database seperti gambar 2 .

4. Use Case Diagram

Use Case diagram merupakan sebuah diagram yang menjelaskan secara umum fungsi dan tanggung jawab dari aktor juga aplikasi dalam sistem informasi yang telah dirancang. Gambar 3 merupakan use case diagram dari aplikasi e-agri.

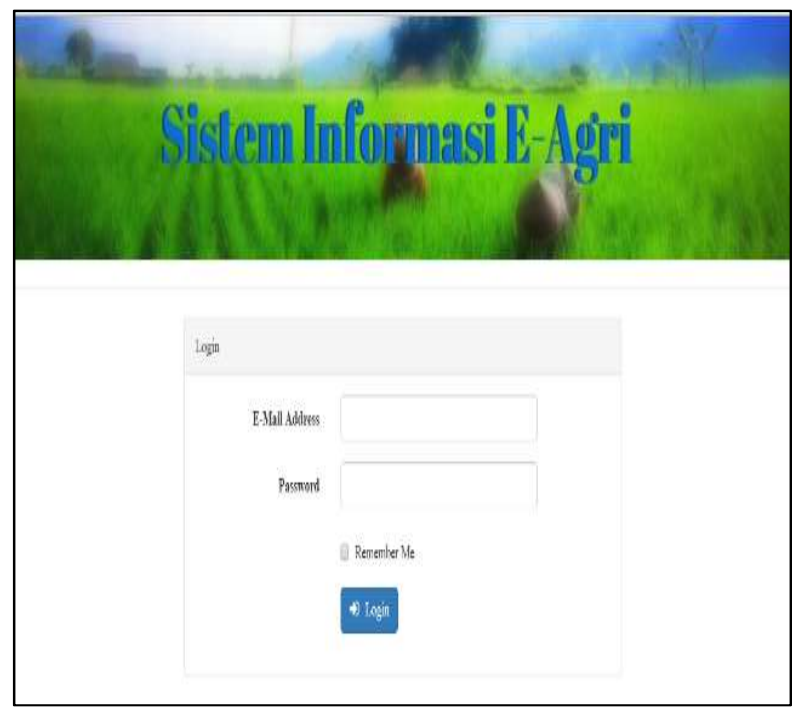

Gambar 7. Halaman Login

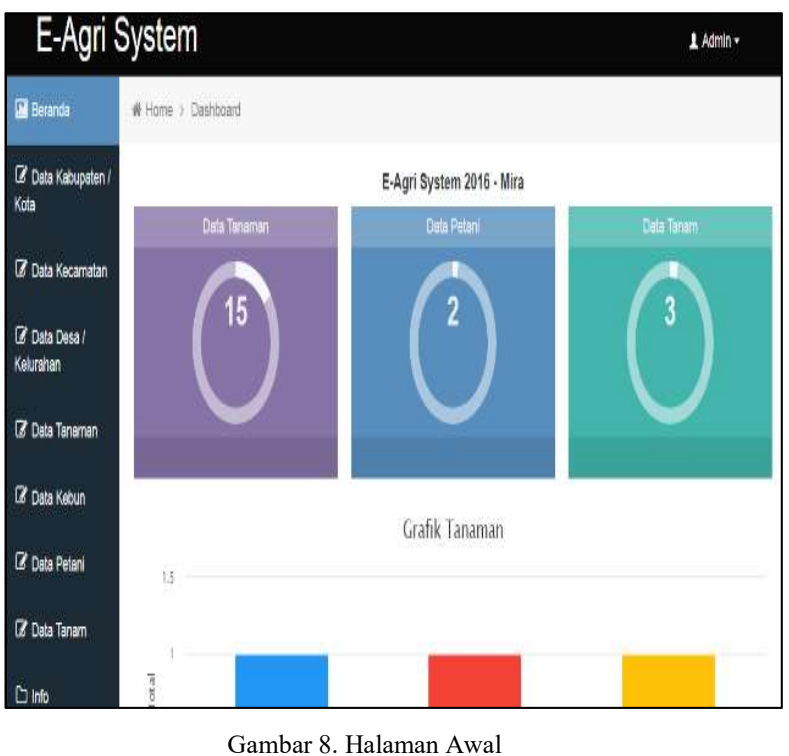

\section{A. Implementasi Sistem \\ IV. HASIL DAN PEMBAHASAN}

Dalam pengoperasian sistem ini diatur dalam 3 jenis pengguna (user) yang masing-masing memiliki otoritas dan tingkatan tertentu dalam mengakses sistem yang berjalan, yaitu :

1. Admin

Pada Halaman ini admin dapat mengolah semua data pada database. Halaman admin juga berfungsi untuk memasukkan, mengedit, menghapus data dan juga dapat menambah user yang bisa mengakses aplikasi e-agri. Dapat dilihat pada Gambar 4.

2. Pengawas atau Asisten

Halaman ini pengawas atau asisten yang mengakses halaman ini berfungsi untuk dapat menambah data saja dengan menu pilihan tambah kota seperti gambar 5. mengolah data seperti ubah dan hapus data tidak ditampilkan seperti pada halaman admin.

3. Petani

Pada halaman ini, petani hanya bisa melihat data yang telah di input oleh admin dan pengawas. Seperti pada gambar 6 menu data kabupaten/kota hanya menampilkan data yang telah diinput. 


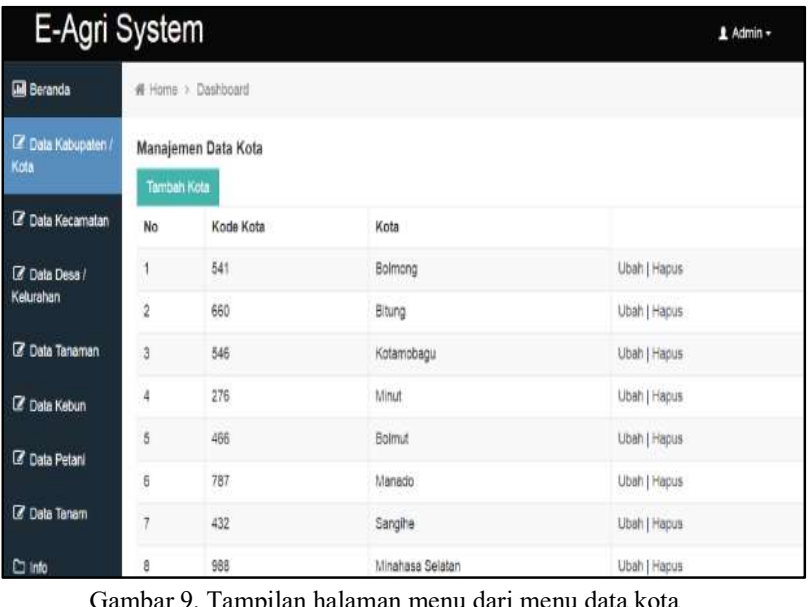

B. Tampilan Aplikasi E-Agri Kabupaten Minahasa Selatan

1. Halaman Login

Halaman awal pada gambar 7 dari aplikasi e-agri berupa tampilan halaman login. Halaman ini merupakan halaman awal dari admin, PPL atau asisten dan petani untuk dapat mengakses sistem. Untuk mengakasesnya diperlukan untuk menginput email address dan password.

2. Halaman Awal

Halaman awal pada gambar 8 merupakan halaman awal dari sistem setelah melakukan login. Pada halaman ini, sistem menampilkan jumlah dari data yang telah diinput dalam bentuk diagram dan grafik.

3. Halaman Menu

Halaman pada gambar 9 merupakan halaman manajemen pendataan data kota. Halaman ini menampilkan kode kota dan nama kota yang diinput pada form tambah data.

4. Halaman form

Halaman ini merupakan form untuk memasukkan data dari setiap menu yang ada pada aplikasi ini. Gambar 10 merupakan tampilan dari halaman form pada menu data kecamatan.

\section{PENUTUP}

A. Kesimpulan :

1. Dengan adanya aplikasi ini dapat mempermudah dan membantu pihak Dinas Pertanian dalam memperoleh data dan informasi dari Kabupaten Minahasa Selatan.

2. Aplikasi E-Agri Kabupaten Minahasa Selatan menggunakan metode pengembangan perangkat lunak Rapid Application Development (RAD) yang merupakan model proses perangkat lunak yang menekankan pada daur pengembangan hidup yang singkat.

3. Dengan menggunakan teknologi internet, penyampaian informasi dapat lebih luas tersebar di berbagai wilayah dan lebih mudah untuk dapat mengaksesnya.

B. Saran :

1. Apabila kedepan ada pengembangan aplikasi ini, maka aplikasi ini bisa dibuat dengan menarik lagi dan dengan adanya fitur pelengkap yang bisa mempermudah dalam penginputan data.

2. Aplikasi dapat dikembangkan menjadi aplikasi mobile android dan IOS.

3. Sebaiknya digunakan program antivirus sehingga dapat mencegah terjadinya kerusakan pada aplikasi ataupun data.

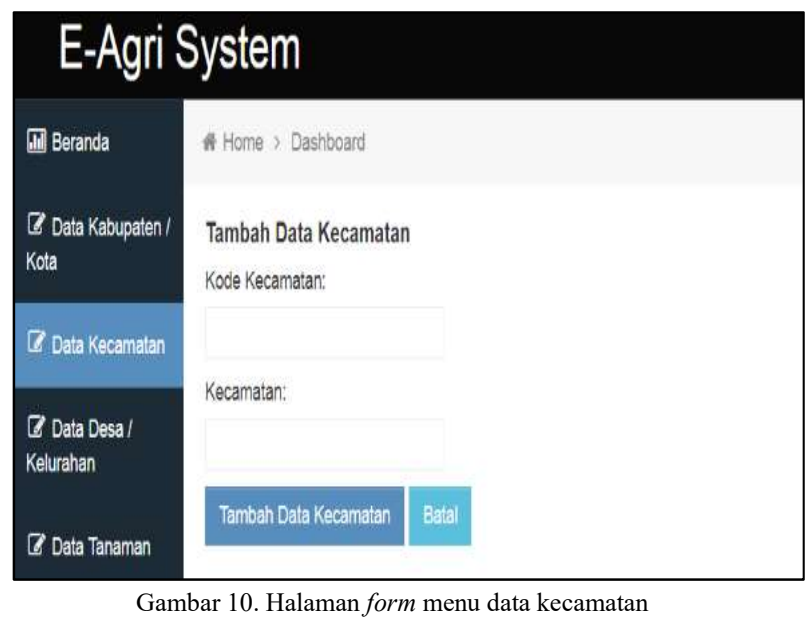

\section{DAFTAR PUSTAKA}

[1] Arfive Gandhi. 2003. Apa itu e-Agriculture. [Online] Tersedia : http://r5alburuj.blogspot.co.id/2013/06/apaitu-e-agriculture/

[2] Apri Saputra, Ananda, Dadang Syarif S,S. Aplikasi Monitoring Hasil Produksi dan Pengingat Jadwal Perawatan Tanaman Kelapa Sawit dengan Perangkat Mobile berbasis Android. 2012.

[3] Emir Satria Hasibuan. 2013. 2012. Sistem Informasi Berbasis Web pada Dinas Pertanian Kabupaten Padang Lawas. Skripsi D-III Teknik Informatika Universitas Sumatera Utara Medan.

[4] Irwin Nugroho. 2011. Sistem Informasi Penerimaan Siswa Baru Berbasis Web dengan PHP dan SQL. Skripsi S1 Teknik Informatika Universitas Negeri Yogyakarta.

[5] M.Hamdan. 2009. Rancang Bangun Sistem Informasi Produksi Pertanian Berbasis Web Di Kabupaten Jombang. Skripsi Teknik Informatika Unibersitas Islam Negeri (UIN) Maulana Malik Ibrahim Malang.

[6] Pressman. Rekayasa Perangkat Lunak Pendekatan Praktisi (Buku Satu) Yongyakarta. 2002.

[7] Sintia Dalalu. 2017. Sistem Informasi Terpadu di Fakultas Teknik Unsrat. Skripsi S1 Teknik Informatika Universitas Sam Ratulangi, Manado.

[8] Siti Nurbaity. 2010. Pengembangan Sistem Informasi Kepegawaian (SIMPEG) Berbasis Web (Studi Kasus : Subbag Administrasi Kepegawaian Pusat UIN Syarif Hidayatullah Jakarta). Skripsi S1 Teknik Informatika UIN Syarif Hidayatullah Jakarta.

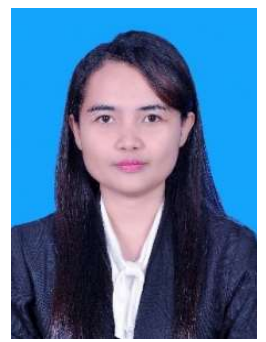

Sekilas dari penulis dengan nama lengkap Miranthy F. Takalelumang, lahir pada tanggal 14 Agustus 1992 di Manado, Sulawesi Utara. Anak ke-1 dari 2 bersaudara, dengan orang tua bernama ayah Lekson Takalelumang dan ibu bernama Dolfina Tamaheang. Dengan pendidikan pertama di Taman Kanak-Kanak Kemala Bhayangkari 1 kemudian melanjutkan ke SD Negeri 103 Manado, melanjutkan ke SMP Katolik St. Theresia Malalayang Manado, dan pada tahun 2007 melanjutkan ke SMK Negeri 1 Manado. Setelah lulus sekolah menengah kejuruan pada tahun 2010 penulis melanjutkan ke Perguruan Tinggi tepatnya di Universitas Sam Ratulangi Manado, Fakultas Teknik, Jurusan Elektro, Program Studi Informatika. Penulis membuat skripsi untuk memenuhi syarat sarjana (S1), dengan judul Aplikasi E-Agri Kabupaten Minahasa Selatan yang di bimbing oleh dua dosen Teknik Informatika yaitu Bapak Yaulie D. Y. Rindengan, ST., Msc., MM dan Bapak Alwin M. Sambul, ST., M.Eng., Ph.D dan mengikuti sidang Skripsi pada tanggal 18 Agustus 2017. 